\title{
Friction Stir Welding Parameters: Impact of Abnormal Grain Growth during Post-Weld Heat Treatment on Mechanical Properties of Al-Mg-Si Welded Joints
}

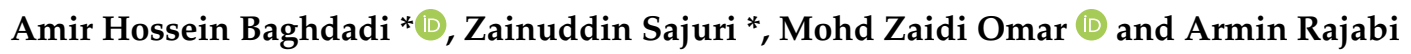 \\ Department of Mechanical and Manufacturing Engineering, Faculty of Engineering and Built Environment, \\ Universiti Kebangsaan Malaysia, Bangi 43600, Selangor, Malaysia; zaidiomar@ukm.edu.my (M.Z.O.); \\ arminrajabi@gmail.com (A.R.) \\ * Correspondence: baghdadi.amirhossein@gmail.com (A.H.B.); zsajuri@ukm.edu.my (Z.S.); \\ Tel.: +60-(3)-8911-8017 (Z.S.)
}

Received: 25 October 2020; Accepted: 24 November 2020; Published: 30 November 2020

\begin{abstract}
Friction stir welding (FSW) is an alternative method to join aluminum (Al) alloys in a solid-state condition. However, the coarsening or dissolution of precipitation hardening phases in the welding zone causes strength reduction or softening behavior in the welded area of age-hardened $\mathrm{Al}$ alloys. Therefore, this research aimed to improve the mechanical properties of an FSW Al-Mg-Si alloy via post-weld heat treatment (PWHT) and the possibility of controlling the abnormal grain growth (AGG) using different welding parameters. FSW was performed with different rotational and travel speeds, and T6 heat treatment was carried out on the FSW samples as the PWHT. The results showed a decrease in the strength of the FSW samples compared with that of the base material (BM) due to the dissolution of precipitation hardening particles in the heat-affected zone. However, the emergence of AGG in the microstructure after the T6-PWHT was identified as the potential event in the microstructure of the PWHT samples. It is found that the AGG of the microstructure in similar joints of Al6061(T6) was governed by the welding parameters. The results proved that PWHT was able to increase the tensile properties of the welded samples to values comparable to that of Al6061(T6)-BM. The increased mechanical properties of the FSW joints were attributed to a proper PWHT that resulted in a homogeneous distribution of the precipitation hardening phases in the welding zones.
\end{abstract}

Keywords: friction stir welding; $\mathrm{Al}-\mathrm{Mg}-\mathrm{Si}$ alloy; abnormal grain growth; heat treatment; microstructure; mechanical properties

\section{Introduction}

The aluminum 6061 (Al6061) alloy is one of the most extensively used alloys in the Al-Mg-Si alloy series. Al6061 is heat-treatable and one of the most versatile materials given its medium-to-high strength requirements and commendable toughness features [1]. Al6061 has been utilized in the automotive industry [2], marine frames, pipelines, and aircraft applications [3]. This alloy has magnesium and silicon as its main alloying elements [4], strengthening the alloy through precipitation hardening [5].

The fusion welding of $\mathrm{Al}$ alloys presents several challenges, e.g., low-melting-point element dissolution and the formation of porosity at the joint interface [6-9]. Cracks may also appear in the joining of heat-treatable $\mathrm{Al}$ alloys. As a solid-state joining procedure, friction stir welding (FSW) is an alternative process to join $\mathrm{Al}$ alloys [10-13]. In this joining process, a rotating tool is driven into the material and moved along the joint interface. The material temperature increases in the welding zone due to friction, and the softened material is extruded around the tool. Then, the tool shoulder 
is applied with a large pressure to forge the material at the joint [14-17]. Material deformation is performed at a temperature lower than the melting point temperature of FSW joints; consequently, it minimizes distortion and residual stresses in comparison with conventional welding methods [18]. Therefore, the issues that arise in the fusion joining of these alloys are absent in FSW [16].

Softening behavior or strength reduction also occurs in the welding zone of FSW heat-treatable Al alloys but to a degree that is considerably lower compared with those that occur in fusion welds [6]. The extent of strength reduction in the welding zone of heat-treatable Al alloys during FSW is dependent on welding parameters; strength reduction occurs despite the application of optimum weld parameters. Softening behavior is obtained due to the dissolution or coarsening of precipitation-hardened particles at the heat-affected zone (HAZ) [19-22].

Heat treatment can be performed to obtain the desired mechanical properties by recovering the precipitation-hardening particles and relieving residual stress on the welded part to improve the loss of strength in the FSW of age-hardened Al alloys. For aluminum alloys, post-weld heat treatment (PWHT) is commonly carried out by solution heat treatments at temperatures above $500{ }^{\circ} \mathrm{C}$, followed by quenching in water and aging at a specific temperature above $170{ }^{\circ} \mathrm{C}$ or natural aging in air [23].

Jamshidi [24] studied the influence of natural aging process on the dissimilar FSW of Al7075 and Al5083. The rotational speeds selected were 900 and $1100 \mathrm{rpm}$, and the travel speed was $100 \mathrm{~mm} / \mathrm{min}$. The results showed no noticeable effects of natural aging on the ultimate tensile strength of the FSW samples after 180 days. In another report, the effect of natural and artificial aging was investigated on the similar FSW of Al2024-T6 after the welding process by Aydin et al. [25]. The welding process was performed at $2140 \mathrm{rpm}$ and $40 \mathrm{~mm} / \mathrm{s}$. The results showed that artificial aging at $190{ }^{\circ} \mathrm{C}$ for $10 \mathrm{~h}$ improved the mechanical properties of the joint more than natural aging after eight months.

Priya et al. [26] carried out the heat treatment process after a dissimilar FSW of Al6061-T6 and Al 2219-T6 with welding parameters of $1600 \mathrm{rpm}$ and $40 \mathrm{~mm} / \mathrm{min}$. The mechanical properties of the FSW samples were improved by PWHT due to the presence of precipitation-hardening particles, whereas abnormal grain growth (AGG) was reported after the PWHT of the welding zones' microstructure. Ipekoglu et al. [27] performed PWHT on Al6061-O and Al6061-T6 after FSW, which was performed with rotational speeds of 1000 and $1500 \mathrm{rpm}$ and travel speeds of 150 and $400 \mathrm{~mm} / \mathrm{min}$, respectively. The improvement of the mechanical properties was reported in both temperature conditions, and the ultimate tensile strengths of heat-treated samples were $80 \%$ and $85 \%$ of the base material (BM) in a similar welding of Al6061-O and Al6061-T6, respectively. However, AGG was reported in these similar joints due to PWHT. Furthermore, Ipekoglu and Çam [28] performed a similar research to investigate the effect of PWHT on the dissimilar FSW of Al6061 and Al7075 in same welding parameters as those mentioned above. An 85\% improvement was found in heat-treated dissimilar joints in the T6 condition, with AGG occurring in the microstructure of heat-treated samples. Pabandi et al. [29] investigated PWHT on the dissimilar FSW of Al6061-T6 and Al2024-T6 performed with welding parameters of 1000 $\mathrm{rpm}$ and $100 \mathrm{~mm} / \mathrm{min}$. A welding efficiency of $80 \%$ was obtained in the PWHT samples, and AGG was reported due to solution heat treatments performed at $520{ }^{\circ} \mathrm{C}$. Therefore, one of the limitations of applying PWHT to the age hardening of Al alloys is the grain growth of welded samples, which decreases the mechanical properties of PWHT samples compared with the BM.

This research aimed to improve the mechanical properties of welded joints via PWHT and the possibility of controlling AGG using different welding parameters. FSW was applied to produce similar joints of Al6061(T6) with different rotational and travel speeds. Then, a T6 heat treatment was performed as PWHT. The microstructural analysis and mechanical properties tests, including tensile tests and microhardness tests, are discussed in detail.

\section{Materials and Methods}

A commercial Al6061(T6) wrought aluminum alloy was used as the BM in this research. Table 1 presents the composition of the alloy and its mechanical properties. Al6061(T6)-BM with a size of $150 \times 50 \times 4 \mathrm{~mm}^{3}$ was considered for the welding process. 
Before the welding process, the surfaces of materials were prepared using a steel brush to remove the oxide layers and then cleaned with acetone. The type of joint configuration was considered a butt joint in the FSW process (Figure 1a). Figure 1b presents the H13 tool steel pin used for FSW with a length of $3.8 \mathrm{~mm}$ and a shoulder diameter of $20 \mathrm{~mm}$. A three-degree tilted angle was applied with the FSW tool during the welding process. Tables 2 and 3 show the welding parameters applied in the welding and PWHT processes. The tool rotational speed varied from 800 to $1400 \mathrm{rpm}$, and traveling speeds were set to 100 and $400 \mathrm{~mm} / \mathrm{min}$. Two sets of joints, i.e., as-welded (FSW) and post-weld heat-treated (PWHT) samples, were produced to investigate the PWHT of the welded joint properties. The PWHT process was carried out as follows: solutionizing at $535^{\circ} \mathrm{C}$ for $1 \mathrm{~h}$ and artificial aging at $175^{\circ} \mathrm{C}$ for $8 \mathrm{~h}$.

Table 1. Chemical compositions and tensile properties of the base material (BM).

\begin{tabular}{ccccccccc}
\hline \multirow{2}{*}{ Material } & \multicolumn{4}{c}{ Chemical Composition (wt. \%) } & & Yield Stress & Ultimate Tensile \\
& Al & Mg & Si & Mn & Cu & & Strength (MPa) \\
\hline Al6061(T6)-BM & Balance & 0.8 & 0.4 & 0.03 & 0.18 & 255 & 290 \\
\hline
\end{tabular}

Table 2. Sample name and welding parameters of similar joints of Al6061(T6).

\begin{tabular}{ccc}
\hline Sample Name & Rotational Speed (rpm) & Travel Speed $(\mathbf{m m} / \mathbf{m i n})$ \\
\hline Sample A-1 & 800 & 100 \\
Sample A-4 & 800 & 400 \\
Sample B-1 & 1000 & 100 \\
Sample C-1 & 1200 & 100 \\
Sample C-4 & 1200 & 400 \\
Sample D-1 & 1400 & 100 \\
\hline
\end{tabular}

Table 3. Sample name and welding parameters of samples with the post-weld heat treatment (PWHT) process.

\begin{tabular}{cccc}
\hline Sample Name & Rotational Speed (rpm) & Travel Speed (mm/min) & PWHT \\
\hline Sample A-1 (PWHT) & 800 & 100 & $\checkmark$ \\
Sample A-4 (PWHT) & 800 & 400 & $\checkmark$ \\
Sample C-1 (PWHT) & 1200 & 100 & $\checkmark$ \\
Sample C-4 (PWHT) & 1200 & 400 & $\checkmark$ \\
\hline
\end{tabular}

Microstructure observation was performed on the cross-section of FSW samples under both conditions (Figure 1c). For microstructure observation, the specimens were cold mounted and manually ground using emery papers ranging from \#600 to \#1200. Then, the specimens were polished using a $1 \mu \mathrm{m}$ particle-size diamond polishing suspension. An etching solution consisting of $1.5 \mathrm{~mL}$ of hydrochloric acid, $2.5 \mathrm{~mL}$ of nitric acid, $1 \mathrm{~mL}$ of hydrofluoric acid, and $95 \mathrm{~mL}$ of distilled water was used to reveal the microstructure of welded joints under an optical microscope.

The tensile test specimen with a gauge length of $40 \mathrm{~mm}$ and a width of $6 \mathrm{~mm}$ was machined from normal to the welding direction (Figure 1c). The tensile test was performed on a $100 \mathrm{kN}$-capacity Zwick/Roell tensile test machine at room temperature. A strain rate of $10^{-3} \mathrm{~s}^{-1}$ was applied in accordance with the ASTM standard E8M-04. The tensile strength was calculated based on the average of three stress values, and joint efficiency was obtained by dividing the ultimate stress of the welded

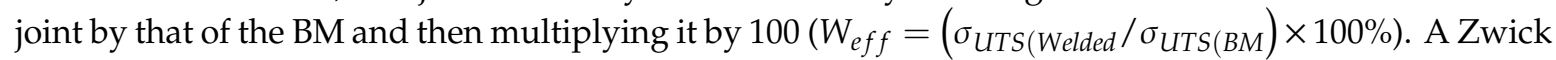
Vickers hardness (HV) tester with a load of $0.1 \mathrm{kgf}$ and a dwell time of $15 \mathrm{~s}$ was employed to evaluate the micro-hardness along the cross-section of the FSW samples. The fracture surfaces of the samples were observed after the tensile test using field emission SEM to study the fracture modes of the samples. 


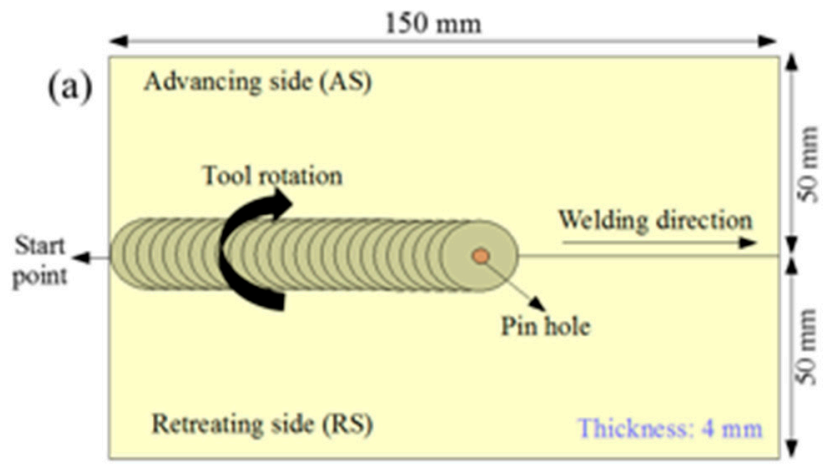

(b)

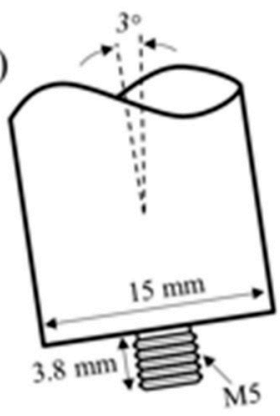

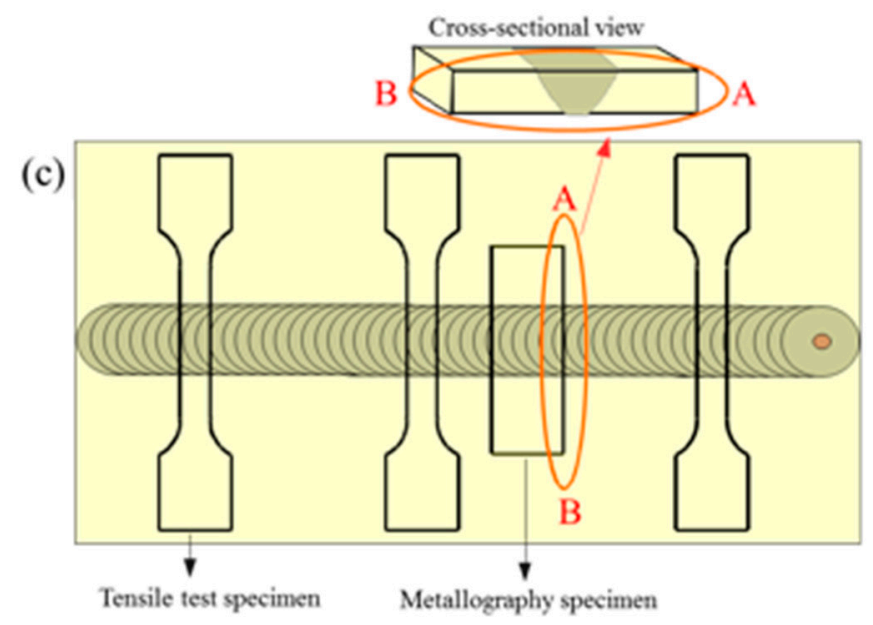

Figure 1. Schematic of the friction stir welding (FSW) process: (a) butt joint configuration, (b) FSW tool, and (c) location of the machined specimens.

\section{Results and Discussion}

\subsection{Microstructure}

No welding defects, such as cracks, tearing, and porosity, were observed on the weld surface. The weld appearance had smooth semi-circular traces, and a flash was formed and pushed out from the welding zone during welding. Figure 2 shows a weld cross-section view of similar joints Al6061(T6) under different welding process parameters.

The macro photos exhibited no welding defects, such as cracks, porosity, or cavities, that commonly occur in welding. The FSW area was divided into three zones, namely the stir zone (SZ), the thermomechanical-affected zone (TMAZ), and the HAZ (Figure 2a). The pin penetration or plunge depth was kept constant at $0.3 \mathrm{~mm}$ in all conditions (Figure $2 \mathrm{~b}$ ). Notably, the amount of dragged material at the middle of the welded sample thickness increased with the increased tool rotational speed from 800 to $1400 \mathrm{rpm}$, which caused a change in the SZ shape from a triangular ( $800 \mathrm{rpm}$ ) to a basin D-shape (1400 rpm) (Figure 2c). This result was attributed to the high temperature imposed on the SZ by the increased rotational speed from 800 to $1400 \mathrm{rpm}$.

Figure 3a shows the optical image of the Al6061(T6)-BM microstructure with an elongated microstructure of inhomogeneous grain size. The elongated microstructure was caused by the cold-working process performed by the supplier company on the samples before T6-heat treatment. Large amounts of round particles were homogeneously distributed at the grain microstructure, as shown in Figure $3 b$. The particles were further analyzed by using energy dispersive X-ray spectroscopy (EDX). Figure 3c,d illustrates the EDX point analysis conducted on round particles containing $61.1 \mathrm{wt} . \%$ of $\mathrm{Mg}$ and $30.7 \mathrm{wt} . \%$ of $\mathrm{Si}$, indicating that they were $\mathrm{Mg}_{2} \mathrm{Si}$ particles. In addition, the rod-like intermetallic particles that co-existed in the microstructure were composed of $63.1 \mathrm{wt} . \% \mathrm{Al}$, $23.5 \mathrm{wt} . \% \mathrm{Fe}$, and $13.3 \mathrm{wt} . \% \mathrm{Si}$. These findings indicate that they were identified as $\mathrm{Fe}_{3} \mathrm{SiAl}_{12}$ particles. 


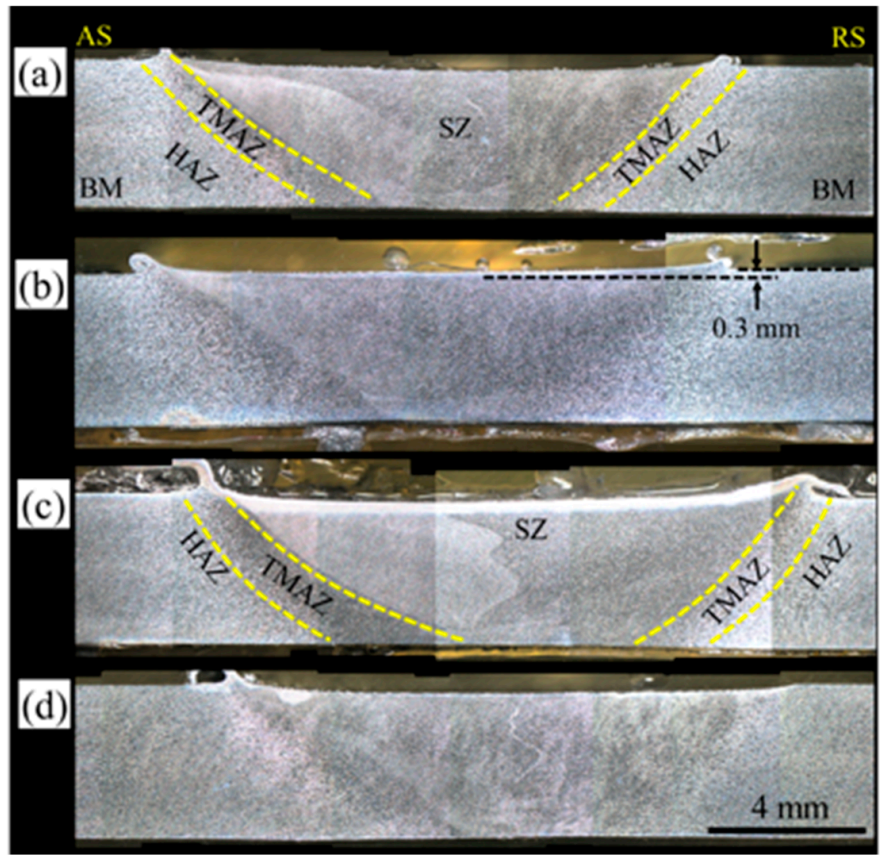

Figure 2. Macro photos of similar joints of Al6061(T6) with different welding parameters: (a) Sample A-1, (b) Sample B-1, (c) Sample D-1, and (d) Sample C-4. SZ: stir zone; TMAZ: thermomechanical-affected zone; and HAZ: heat-affected zone.

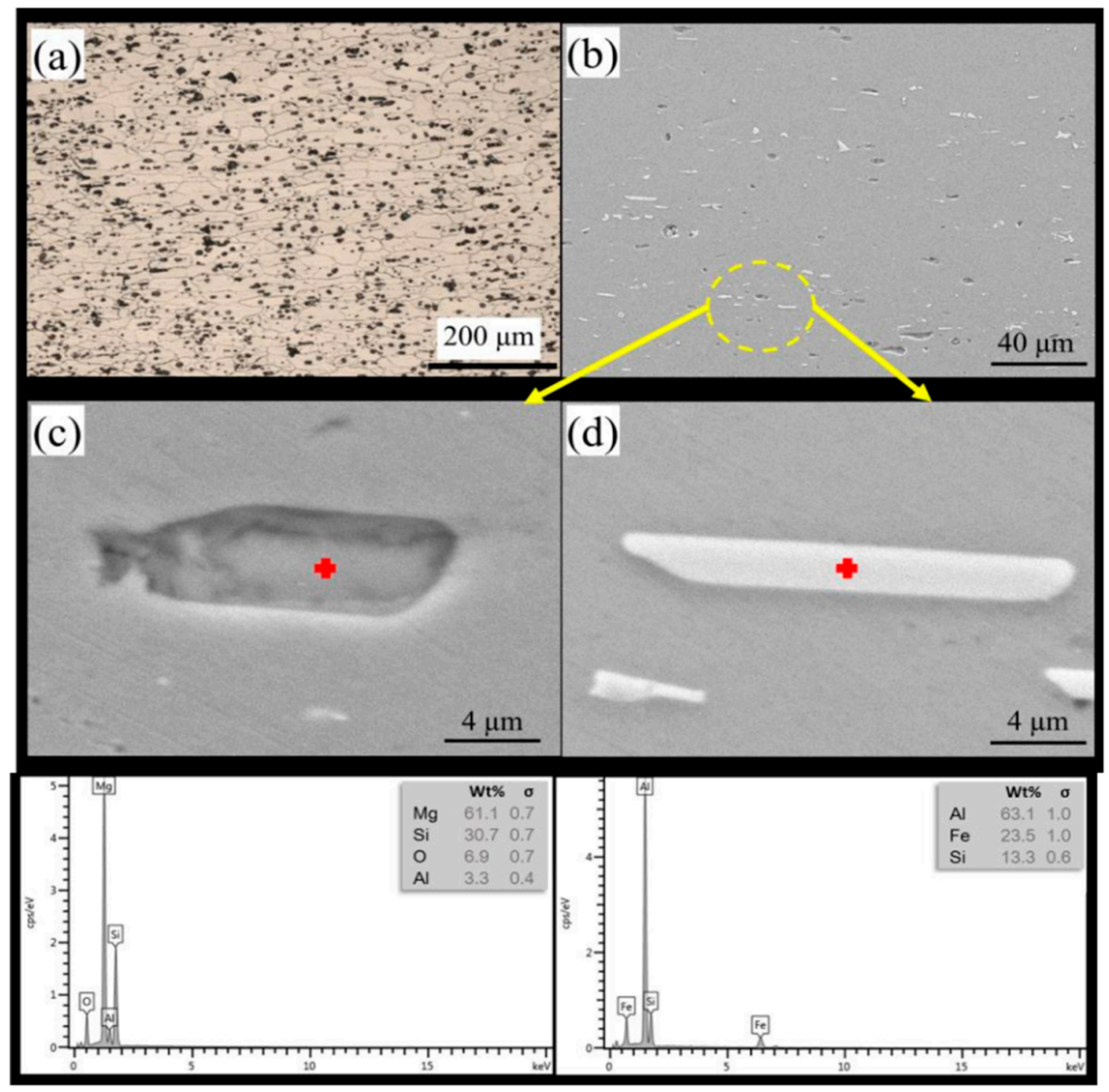

Figure 3. Microstructure of Al6061(T6)-BM: (a) optical image, (b) FE-SEM image, and (c,d) energy dispersive $\mathrm{X}$-ray spectroscopy (EDX) point analysis. 
Figure 4 illustrates the effect of the FSW process on the microstructure in the welding zone of the FSW sample at a rotational speed of $1200 \mathrm{rpm}$ and a $100 \mathrm{~mm} / \mathrm{min}$ travel speed. The SZ microstructure was composed of fine and equiaxed grains due to frictional heat and severe plastic deformation during welding, as shown in Figure 4a. The BM underwent severe plastic deformation due to the stirring and heat during FSW, causing a dynamic recrystallisation phenomenon in the material. The dynamic recrystallisation contributed to grain refinement in the SZ microstructure [30,31].

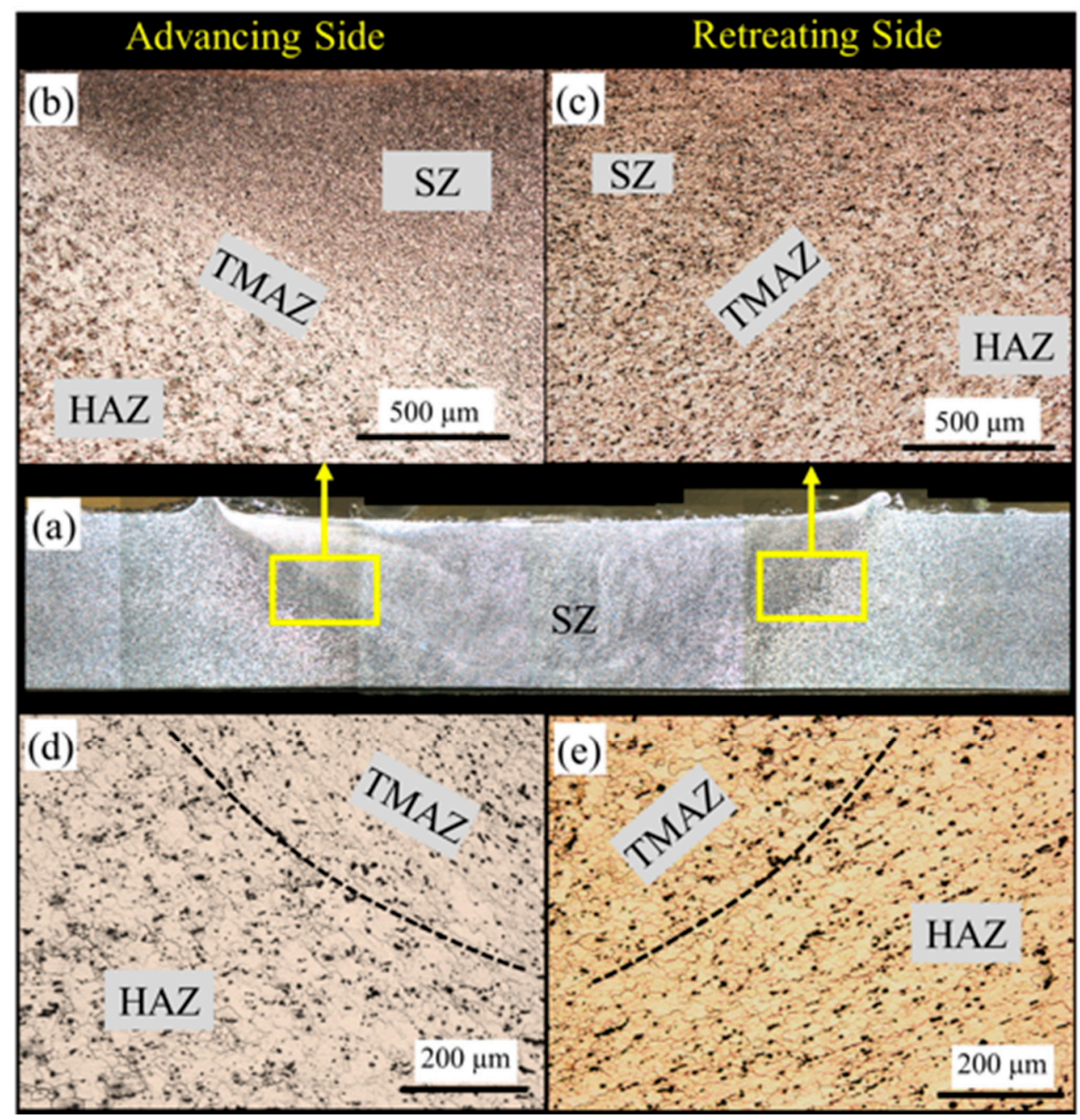

Figure 4. Microstructure of similar joints of Al6061(T6) at Sample C-1: (a) cross section view; $(\mathbf{b}, \mathbf{c})$ low-magnification advancing side (AS) and retreating side (RS), respectively; and (d,e) high-magnification views of $(\mathbf{b}, \mathbf{c})$, respectively.

Figure $4 b, c$ shows the different zones of the SZ, the TMAZ, and the HAZ in the advancing side (AS) and retreating side (RS), respectively. The figures reveal the recrystallized and fine grains in the SZ on both sides of the welding zones, i.e., the AS and RS. Figure 4 d,e displays the high-magnification transition zone between the SZ and BM involved in the TMAZ and the HAZ. The TMAZ was subjected to plastic deformation and heat treatment, but the degree of change was lower than that of the SZ. The grains in the TMAZ were deformed and elongated towards the direction of rotation and followed the pattern of the SZ (Figure 4). Moreover, the HAZ underwent heat treatment as a result of heat transfer from the SZ and the TMAZ. Therefore, the grain size was coarser than that of the TMAZ. BMs experienced a high temperature of up to $400{ }^{\circ} \mathrm{C}$ in the SZ [32] during welding due to the frictional heat between the tool and BM, thus causing the annealing effect. Annealing led to the coarsening and dissolution of strengthening elements, which included $\mathrm{Mg}_{2} \mathrm{Si}$, in the aluminum 
matrix. The precipitation hardening particles that were present as strengthening elements in the BM of Al6061(T6) dissolved or coarsened in the SZ or the TMAZ due to the higher temperatures of those areas than that of the HAZ. The spread precipitation hardening particles disappeared and dissolved into the Al matrix with the increased in rotational speeds from 800 to $1400 \mathrm{rpm}$ compared with those in the Al6061(T6) BM side because of the increase in temperature. The HAZ experienced a thermal cycle due to an increase in temperature of up to $250{ }^{\circ} \mathrm{C}$ [33]. The increase in temperature in the HAZ due to increased rotational speeds could have led to the enlargement of the average grain size.

Figure 5 presents the SZ microstructures of the welded samples at rotational speeds of 800 and $1200 \mathrm{rpm}$ and travel speeds of 100 and $400 \mathrm{~mm} / \mathrm{min}$. The dissolution of precipitation hardening particles occurred as a result of increased rotational and travel speeds. The figure shows that the microstructures of the SZs showed more recrystallized fine grains compared with that of the BM. At a constant travel speed of $100 \mathrm{~mm} / \mathrm{min}$, no significant increase in grain was observed with the increase in rotational speed. However, at a constant rotational speed, an increase in the grain size of the SZ was determined by an increase in the welding travel speed due to the low heat input and plastic deformation reduction. When the rotational speed of the FSW was constant, the amount of plastic deformation and heat exposure at the welding zone decreased with the increase in travel speed during welding. According to the recrystallisation principle, coarse recrystallized grains are caused by the decrease in plastic deformation during welding [34]. A small and fine grain microstructure was obtained because of the reduction in heat input during welding. Thus, the grain size was affected by two factors, i.e., plastic deformation and heat input [35].

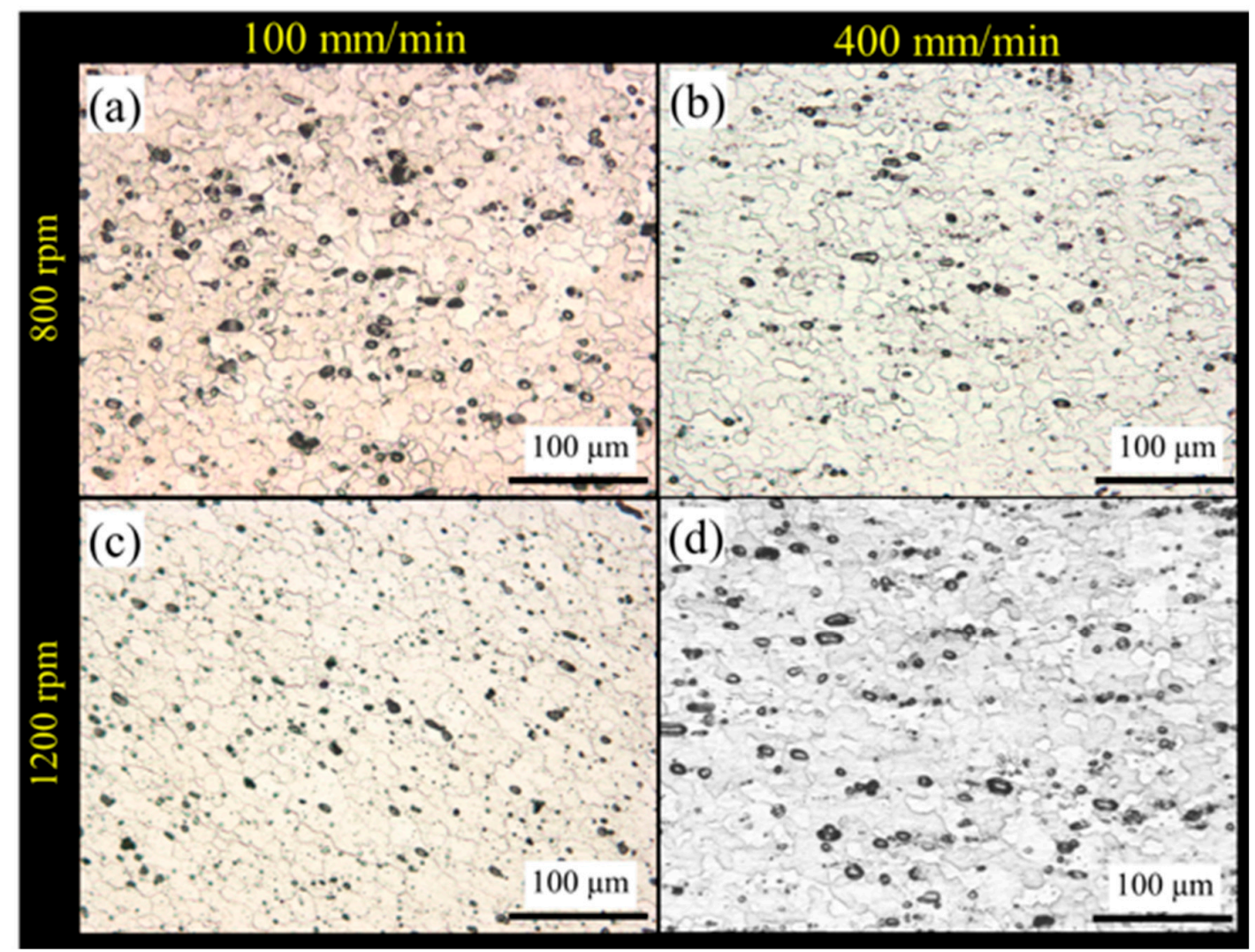

Figure 5. Microstructures of the SZs of similar joints for Al6061(T6): (a) Sample A-1, (b) Sample A-4, (c) Sample C-1, and (d) Sample C-4.

In general, T6 heat treatment, which involves the solutionizing and precipitation hardening processes, can be performed to increase the strength of heat-treatable Al alloys [24,29,36]. Employing the same approach, T6 heat treatment was applied to similar joints of Al6061(T6) FSW samples to 
evaluate the effect of PWHT on the microstructure and mechanical properties of the joints. Similar joints of Al6061(T6) samples that were joined at rotational speeds of 800 and $1200 \mathrm{rpm}$ with two travel speeds of 100 and $400 \mathrm{~mm} / \mathrm{min}$ were subjected to T6-PWHT. Figure 6 shows the cross-section of PWHT Al6061(T6) under different welding parameters. The microstructural change in the welding zone was evident after PWHT under both conditions, and no defects were observed in the cross-sections of the samples.

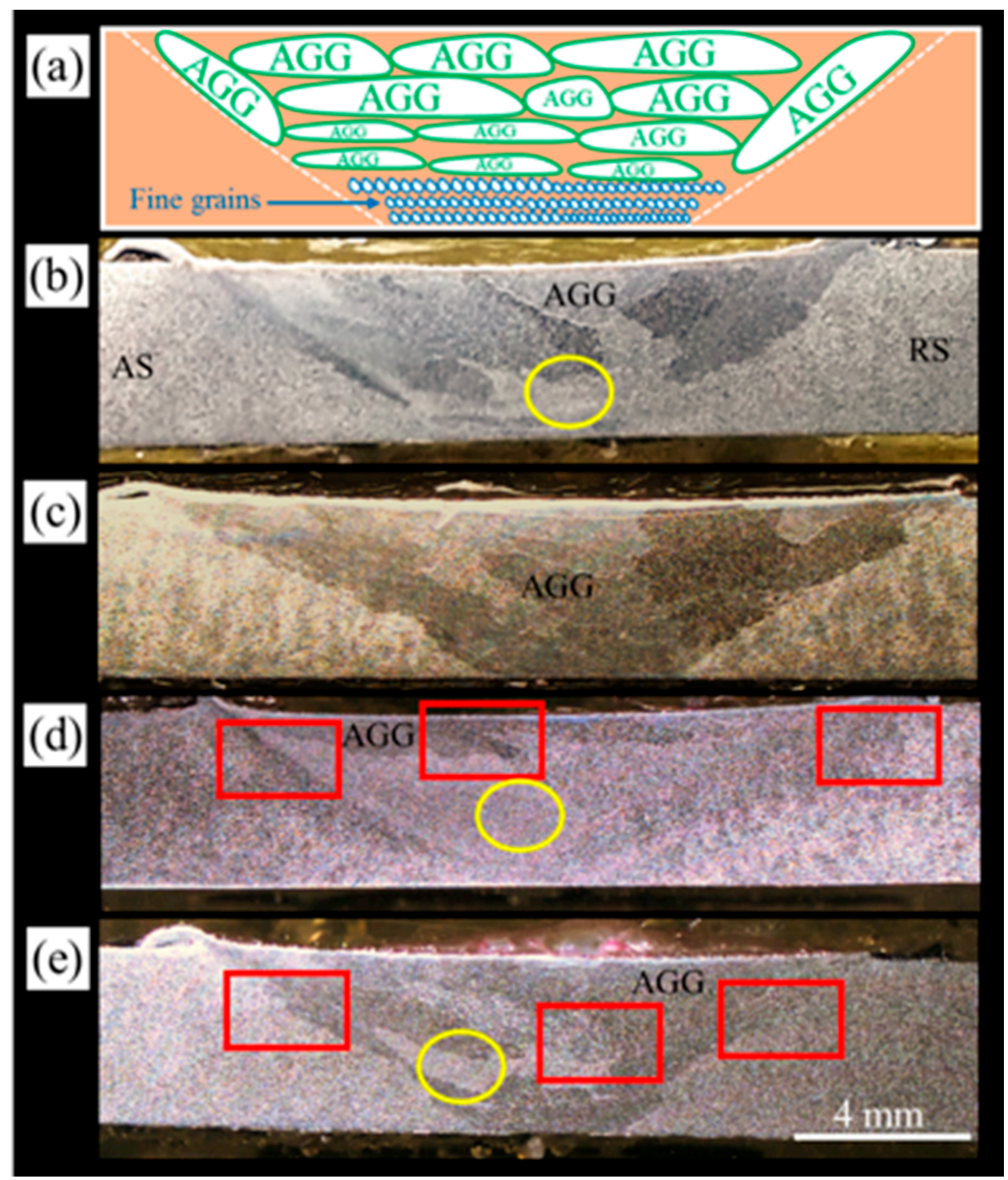

Figure 6. Macro photos of PWHT Al6061(T6) samples: (a) Schematic of weld cross-section, (b) Sample A-1 (PWHT), (c) Sample A-4 (PWHT), (d) Sample C-1 (PWHT), and (e) Sample C-4 (PWHT) (marks show the area for detailed microstructure observation).

The grain growth in the welding zone was the significant effect of PWHT on the microstructure of the FSW samples. Figure 7 shows the AS, the SZ, and the RS of welding zones in the PWHT samples at a rotational speed of $1200 \mathrm{rpm}$ and different travel speeds, as indicated by the red rectangle in Figure 6d,e. The TMAZ width in both sides of the welding zone, i.e., AS and RS, decreased or diminished in the microstructure of the PWHT samples (Figure 7a-d) compared with that under the as-weld condition (Figures 2 and 4). The grain size in the SZ increased to several hundred microns and up to several millimeters (Figure 7e,f). This phenomenon, the instability of the microstructure of the welding zone, is called AGG. 


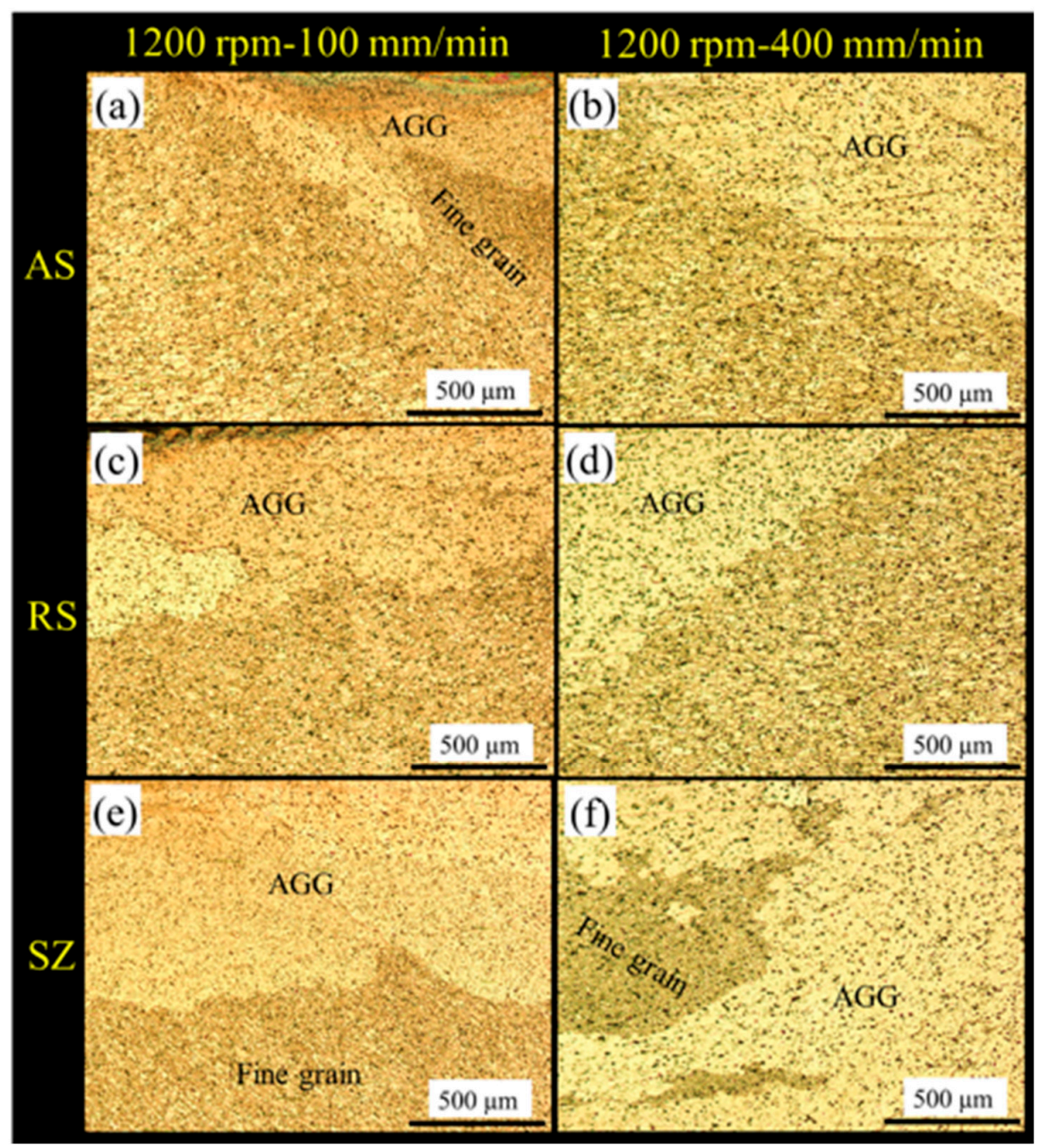

Figure 7. Abnormal grain growth (AGG) in the microstructure of welding zone in PWHT Al6061(T6) samples.

In general, three factors can affect the occurrence of AGG: (i) anisotropy in grain boundary energy and mobility, (ii) a decrease in pinning forces due to coarsening and precipitation hardening particles dissolution, and (iii) thermodynamic driving forces due to grain size distribution [37]. Thus, the balance between the thermodynamic driving force occurring in AGG and the barrier migration of grain boundaries, which are pinning forces, is a critical feature that should be considered.

Gottstein [38] indicated that the SZ has a recrystallized microstructure with high-angle grain boundaries. In this study, no sufficient driving force was observed in the FSW zone to restart recrystallisation as soon as the static high temperature was applied. Thus, grain growth and coarsening are a promising consequence of PWHT when the heat energy from PWHT at $540{ }^{\circ} \mathrm{C}$ is high enough to be the driving force for grain growth. Consequently, an inhomogeneous microstructure in the different zones of FSW was the main factor the AGG determined in the FSW zone. The PWHT applied to the FSW samples involved a solution heat treatment that influenced the grain stability of joints. Chen et al. [39] stated that grain growth area increases as the temperature of the solution heat treatment increases. PWHT was applied to the FSW samples under the same conditions in this study. Therefore, this research focused on the effect of welding parameters on AGG.

As shown in Figure 6e, AGG covered majority of the area of the welding zone cross-section under the welding conditions of $1200 \mathrm{rpm}$ and $400 \mathrm{~mm} / \mathrm{min}$ after PWHT. However, the area covered by AGG in the joint sample at $1200 \mathrm{rpm}$ and $100 \mathrm{~mm} / \mathrm{min}$ was significantly smaller compared to the area covered by the fine grains revealed in the cross-section after PWHT, as shown in Figure 6d. 
Welding parameters influenced the heat input and the corresponding thermal cycle. Heat input is inversely related to the weld pitch $(\mathrm{W} / \mathrm{P})$, which is the ratio of travel speed and rotational speed $(v / \omega)$, thus indicating that a low W/P value results in a high heat input. Thus, the W/P calculated (Table 4) under the welding parameters of $1200 \mathrm{rpm}$ and $400 \mathrm{~mm}(1 / 3)$ was $1 / 3$. This value was larger than at $1200 \mathrm{rpm}$ and $100 \mathrm{~mm} / \mathrm{min}$, which was 1/12. AGG also occurred at a travel speed of $400 \mathrm{~mm} / \mathrm{min}$ due to the low heat input. The proportional heat index should be considered to discuss the AGG phenomenon at different travel speeds [40]. The term is defined as the ratio of travel speed and the square of rotational speed $\left(v / \omega^{2}\right)$ (Table 4$)$. When the heat index is small, AGG occurs less. In our study, AGG could occur at a travel speed of $400 \mathrm{~mm} / \mathrm{min}$ and a constant rotational speed of $1200 \mathrm{rpm}$. Thus, this phenomenon showed a good agreement between the heat input and heat index values and revealed the microstructure of PWHT Al6061(T6). This finding also showed that the increase in welding rotational and travel speeds effectively induced AGG in the welding zone of the PWHT Al6061(T6) samples. Thus, AGG can be controlled after PWHT by welding parameters that are a combination of welding travel and rotational speeds with similar FSW.

Table 4. Effect of welding travel speed on weld pitch (W/P) and heat index.

\begin{tabular}{cccc}
\hline $\begin{array}{c}\text { Welding Rotational } \\
\text { Speed (rpm) }\end{array}$ & $\begin{array}{c}\text { Welding Travel } \\
\text { Speed (mm/min) }\end{array}$ & W/P & Heat Index $\left(\times \mathbf{1 0}^{-\mathbf{2}}\right)$ \\
\hline \multirow{2}{*}{800} & 100 & $1 / 8$ & $1 / 64$ \\
& 400 & $1 / 2$ & $1 / 16$ \\
\multirow{2}{*}{1200} & 100 & $1 / 12$ & $1 / 144$ \\
& 400 & $1 / 3$ & $1 / 36$ \\
\hline
\end{tabular}

Figure 8 displays the fine grains in the welding zone of PWHT Al6061(T6) (yellow circle in Figure 6). In the fine microstructure found in the welding zone, the average grain size increased but non-significantly. The precipitation hardening distribution and size increased via PWHT compared with those under the as-weld condition. Therefore, evaluating the mechanical properties of the PWHT Al6061(T6) samples was necessary to identify the effect of AGG and PWHT on the FSW samples.

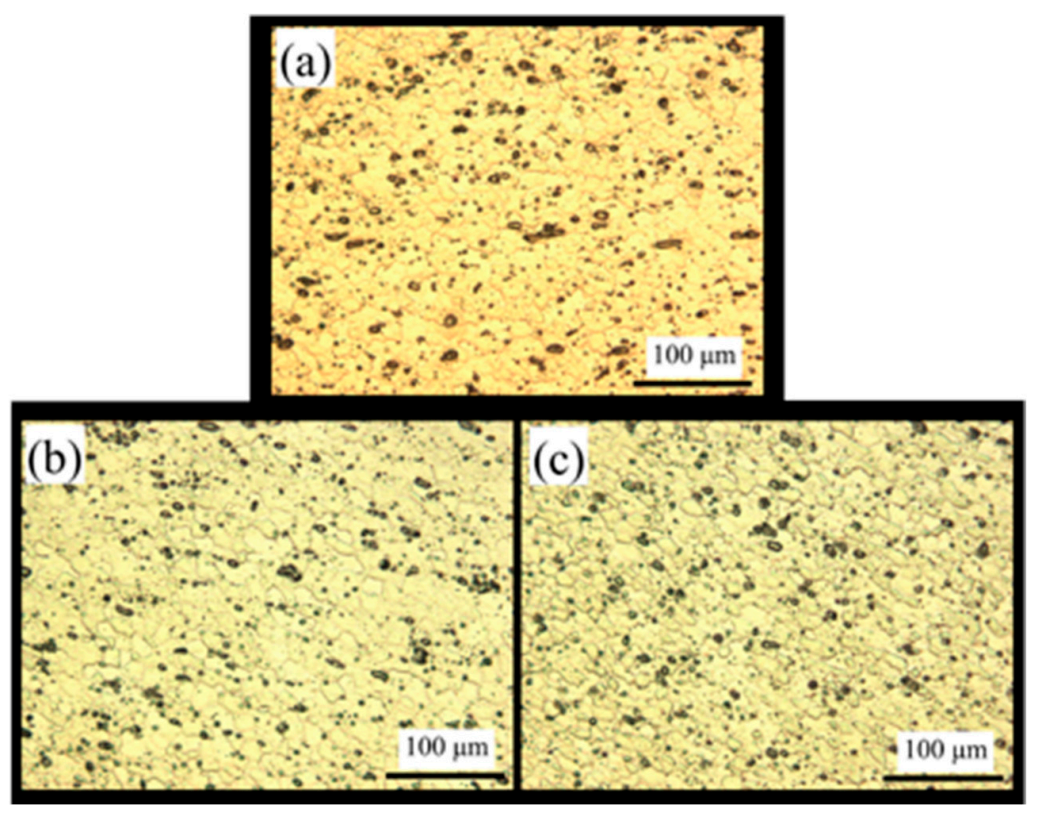

Figure 8. High-magnification of the SZ in PWHT Al6061(T6) samples: (a) Sample A-1 (PWHT), (b) Sample C-1 (PWHT), and (c) Sample C-4 (PWHT). 


\subsection{Mechanical Properties}

\subsubsection{Tensile Properties}

Tensile tests were performed on similar Al6061(T6) joints with different welding parameters. Table 5 tabulates the transverse tensile strength of the similar-joint samples with different welding parameters, showing the ultimate tensile stress, elongation, and joint efficiency ( $\left.W_{\text {eff }}\right)$. The tensile strength and elongation of the FSW samples were lower than those of BM, which showed a tensile strength reduction of about $38 \%$ due to grain coarsening in the HAZ and the overaging of the strengthening phase. Grain coarsening in the microstructure caused a decrease in mechanical strength and a joint sample failure from the HAZ. No noticeable effect of different rotational speeds on the tensile strength of the FSW samples was observed at a constant travel speed of $100 \mathrm{~mm} / \mathrm{min}$.

Table 5. Tensile properties of similar joints of Al6061(T6).

\begin{tabular}{cccc}
\hline Sample & $\begin{array}{c}\text { Ultimate Tensile Strength } \\
(\mathbf{M P a})\end{array}$ & $\begin{array}{c}\text { Elongation } \\
\mathbf{( \% )}\end{array}$ & $\begin{array}{c}\text { Joint Efficiency } \\
\mathbf{( \% )}\end{array}$ \\
\hline Sample A-1 & 180 & 7.2 & 62 \\
Sample A-4 & 207 & 7.9 & 69 \\
Sample B-1 & 179 & 7.9 & 62 \\
Sample C-1 & 182 & 7.8 & 63 \\
Sample C-4 & 210 & 8.4 & 72 \\
Sample D-1 & 178 & 7.8 & 61 \\
\hline
\end{tabular}

However, under the same rotational speed (i.e., 800 and $1200 \mathrm{rpm}$ ), the ultimate tensile stress of similar joints increased as the travel speed increased from 100 to $400 \mathrm{~mm} / \mathrm{min}$. In particular, the ultimate tensile stress increased by $15 \%$ from 100 to $400 \mathrm{~mm} / \mathrm{min}$. Liu et al. [35] and Ji et al. [41] reported that the tensile strength of the FSW samples increased as the travel speed increased. In this study, the increase in travel speed caused no significant effect on the elongation, which was approximately $8 \%$ under all welding conditions. Furthermore, as the tensile strength increased, the welding efficiency increased and reached $72 \%$ at $1200 \mathrm{rpm}$ and $400 \mathrm{~mm} / \mathrm{min}$. The ductility of the welded samples decreased after the welding process because of the limited plasticity (i.e., strain concentration) in the welded samples through tensile testing. Strength undermatching and low ductility have also been described in recent research on the welding of age hardening $\mathrm{Al}$ alloys [42,43].

Figure 9 shows the stress-strain curves of the FSW and PWHT samples under different welding conditions. The serration behavior caused by the Portevin-Le Chatelier effect [44] was observed before $\sigma_{U T S}$ points in the as-welded samples. This serrated yielding represents the plastic instability during the tensile test $[44,45]$.

PWHT, including the solutionizing and artificial aging processes, increased the tensile strength and improved the ductility of the FSW Al60661(T6) samples (Figure 9). The tensile strength improvement was contrary to the characteristic of the microstructure obtained after PWHT. The microstructure of the PWHT samples revealed that the grain size increased and the AGG phenomenon occurred in the welding zone. However, when the grain size increased, the tensile strength should have decreased in accordance with the Hall-Petch equation [46]. Pabandi et al. [29] stated the same finding in the dissimilar FSW of Al2024(T6) and Al6061(T6), revealing that the mechanical properties improved after PWHT as the average grain size in the welding zone increased. It is believed that the increase in tensile properties could be attributed to the formation of precipitation hardening particles that were recovered after the PWHT. 


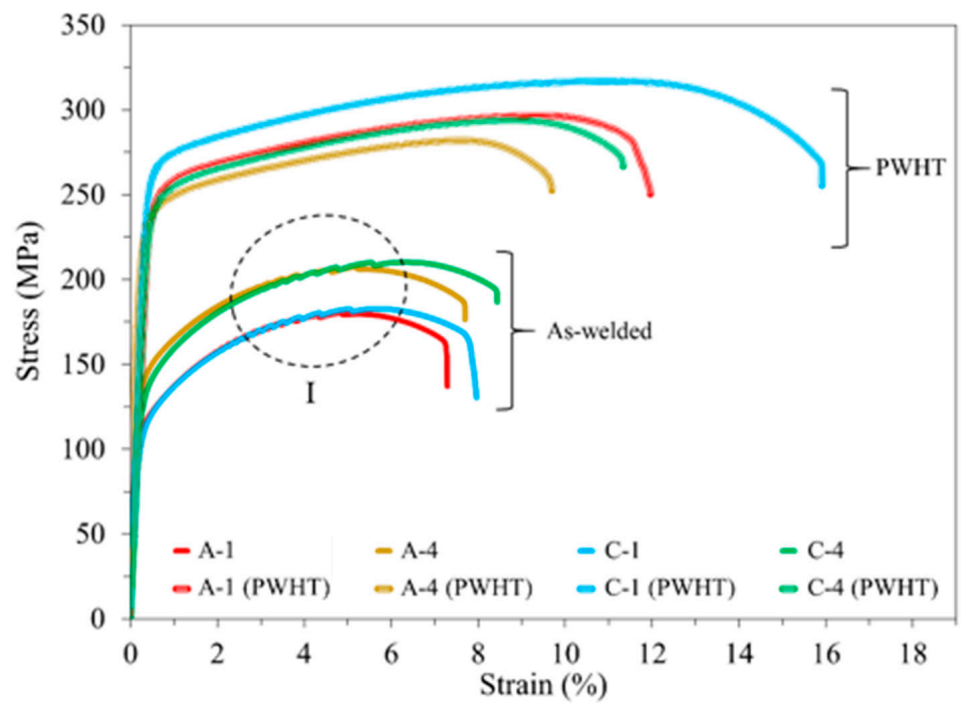

Figure 9. Stress-strain curves of FSW and PWHT samples.

Figure 10 shows a detailed comparison of the effect of PWHT on the tensile properties of FSW Al6061(T6). The yield stress of samples welded at a travelling speed of $100 \mathrm{~mm} / \mathrm{min}$ after the PWHT (Sample A-1 (PWHT) and Sample C-1 (PWHT)) was double the value that of the as-FSW (Sample A-1 and Sample C-1). Additionally, the ultimate tensile strength increased by up to $64 \%$ and $74 \%$, respectively, for Samples A-1 and C-1. For samples welded at a travelling speed of $400 \mathrm{~mm} / \mathrm{min}$, the yield stress after the PWHT (Sample A-4 (PWHT) and Sample C-4 (PWHT)) was increased by more than $70 \%$ of the value of the as-FSW (Sample A-4 and Sample C-4). Additionally, the ultimate tensile strength increased up to more than $38 \%$ for both samples after the PWHT. The maximum ultimate stress was obtained at $316 \mathrm{MPa}$ with a $15.1 \%$ elongation at the welding parameters of $1200 \mathrm{rpm}$ and $100 \mathrm{~mm} / \mathrm{min}$. As shown in the microstructure at a rotation speed of $1200 \mathrm{rpm}$, the grain size of the PWHT samples at $100 \mathrm{~mm} / \mathrm{min}$, which presented high tensile properties, was smaller than that of the PWHT samples at $400 \mathrm{~mm} / \mathrm{min}$. A nonhomogeneity was observed in the PWHT samples in the SZ, and this condition could have influenced the elongation of the PWHT samples. The fluctuation of ductility in the PWHT samples was due to the strength undermatching nature of the joints, i.e., the existence of a region consisting fine and abnormally large grains [47]. This means that the weld zone plastically deformed and failed while the BM remained in the elastic region [27].

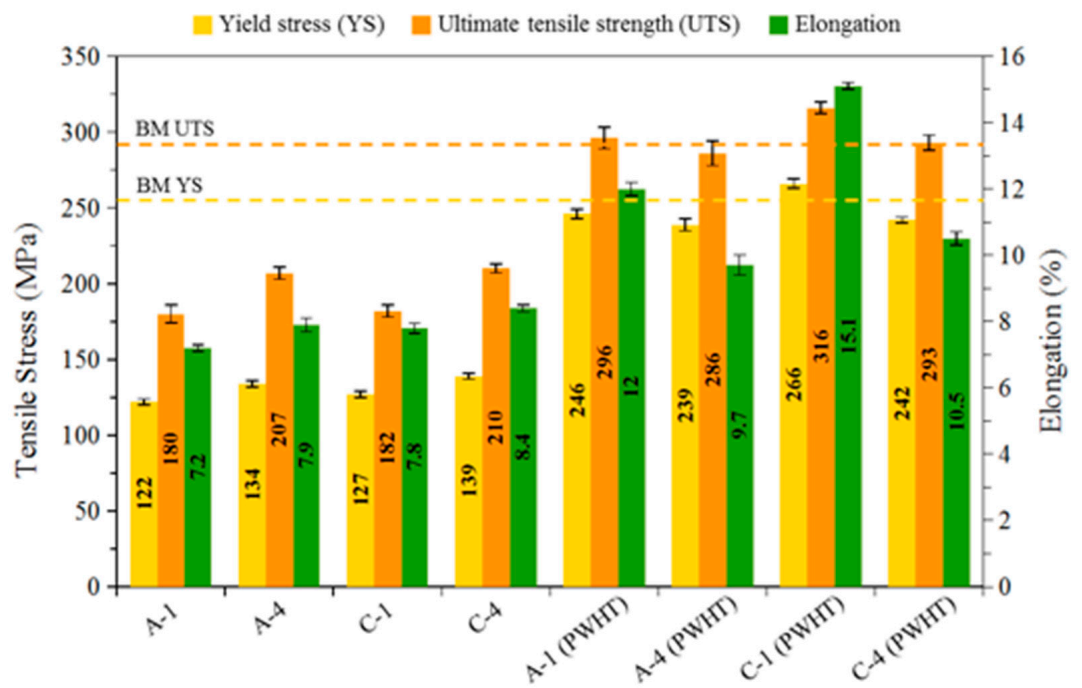

Figure 10. Effects of PWHT on the tensile properties of FSW Al6061(T6). 


\subsubsection{Fractography}

The failure position of similar-joint samples was examined under different welding parameters (Figure 11). All the defect-free FSW samples exhibited a necking phenomenon at the fracture location under all welding conditions. Figure 11 presents the fracture locations of similar joint samples outside the welding zone. Fracture and necking occurred at the HAZ adjacent to the TMAZ [48]. This fracture was located after the tensile test of all similar FSW samples under different welding parameters. The failure position of the PWHT Al6061(T6) samples was also examined under different welding parameters. Fracture and necking occurred at the center of the PWHT samples (Figure 11). The same fracture area was formed after the tensile test for the other PWHT samples.

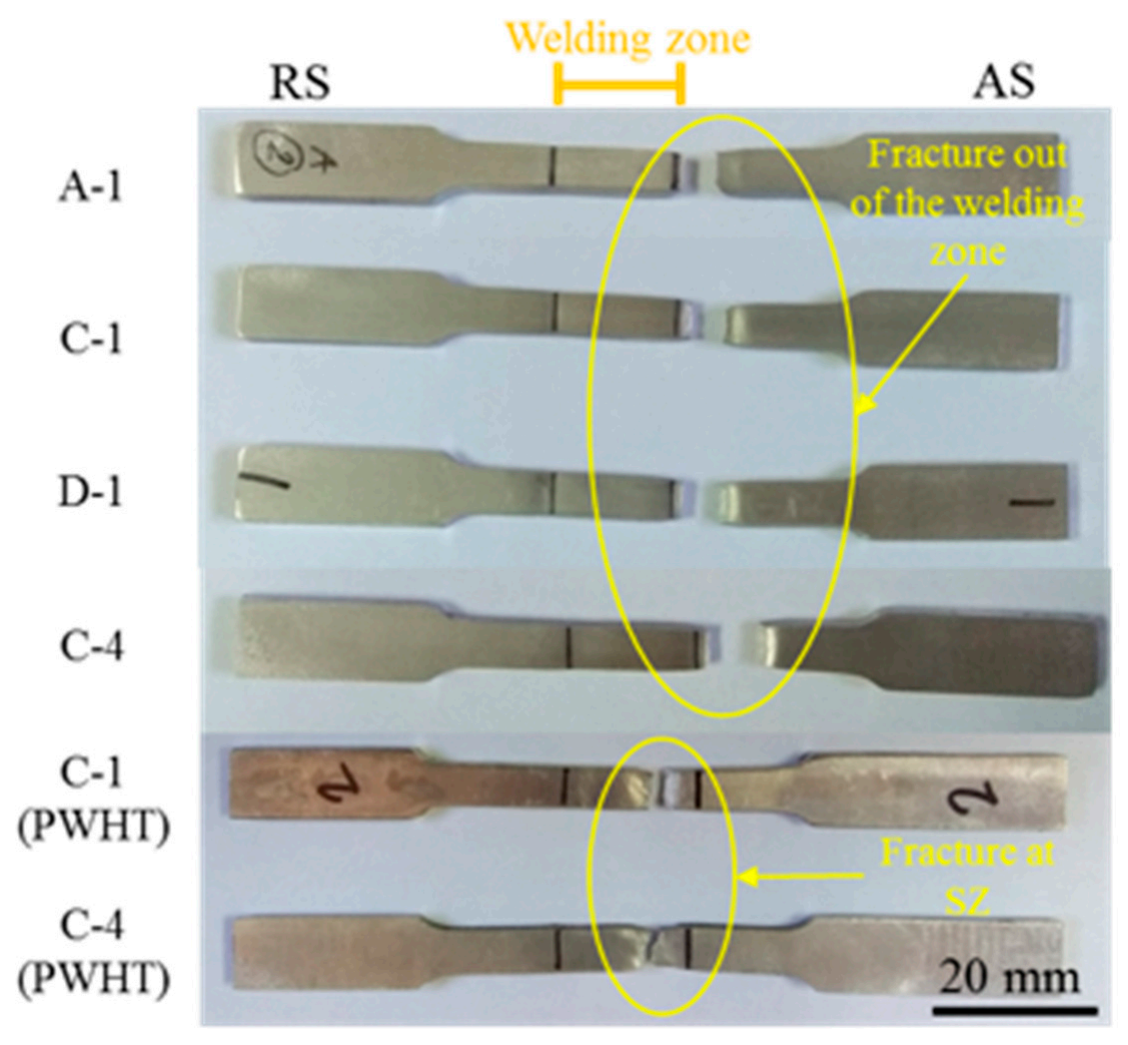

Figure 11. Failure position of similar joints of Al6061(T6) after the tensile test.

The fracture surface of similar FSW samples was analyzed under different welding parameters by SEM (Figure 12). As seen in Figure 12a, the size of the dimples on the fracture surface of Al6061(T6)-BM differed from those of similar-joint samples. The size of the dimples in the BM was smaller than those in similar-joint samples without heat treatment. This was the manifestation of higher tensile strength of the BM compared with those of the welded samples, as shown in Figure 12b-e. The shallow and a smaller number of dimples observed on the fracture surfaces in the welded samples indicated a lower ductility in welded joints [41,49].

Figure 12f,g displays the tensile fracture surfaces of the PWHT samples. Fine dimples were also observed on the fracture surfaces of the PWHT specimens. The morphologies of the fracture surface of the PWHT samples were similar to that of the fracture surface of Al6061(T6)-BM (Figure 12a). Cleavage and ridge facets were observed on the fracture surface of the PWHT samples shown in Figure 12h. The tensile strengths of the PWHT samples that exhibited smaller dimples in the fracture surfaces were higher than those in the FSW samples. 


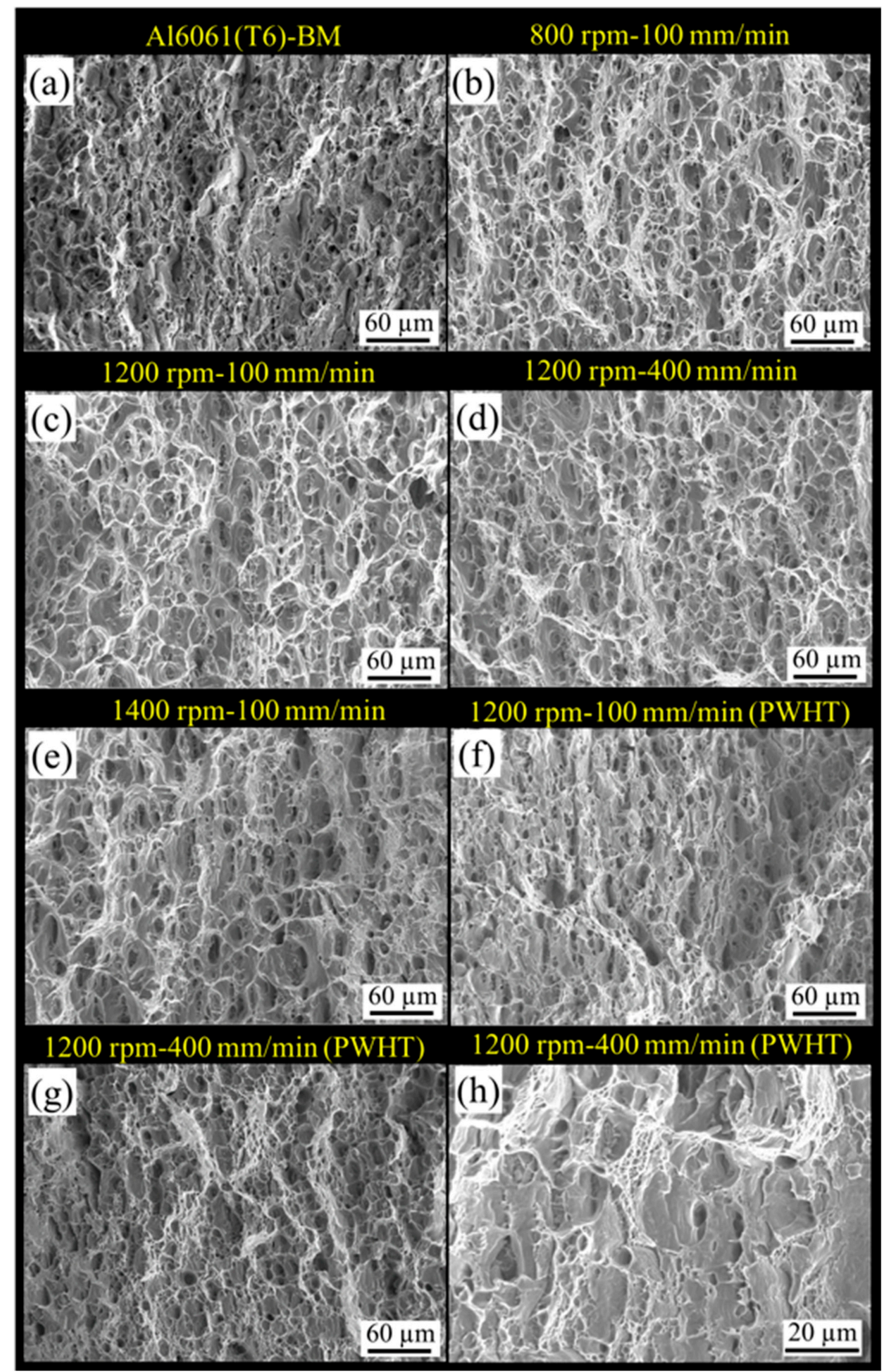

Figure 12. Tensile fracture surfaces of similar joints of Al6061(T6). 


\subsubsection{Hardness Profile}

Figure 13 shows the hardness (HV) distribution profile of the middle cross-sectional thickness of the FSW and PWHT samples. The distribution of the hardness profile of a ' $W$ ' shape was obtained from the FSW samples, corresponding to three distinct welding zones, namely the SZ, the TMAZ, and the HAZ. The lowest hardness values were measured at the HAZ adjacent to the TMAZ on the AS (Figure 13) under all welding conditions, as highlighted in the black dotted circle. A good agreement was observed with the failed FSW samples after the tensile tests. In particular, the fracture location was detected in the HAZ. In general, the hardness values in the welding zone of the FSW samples decreased compared with that of Al6061(T6)-BM with a value of 93-97 HV.

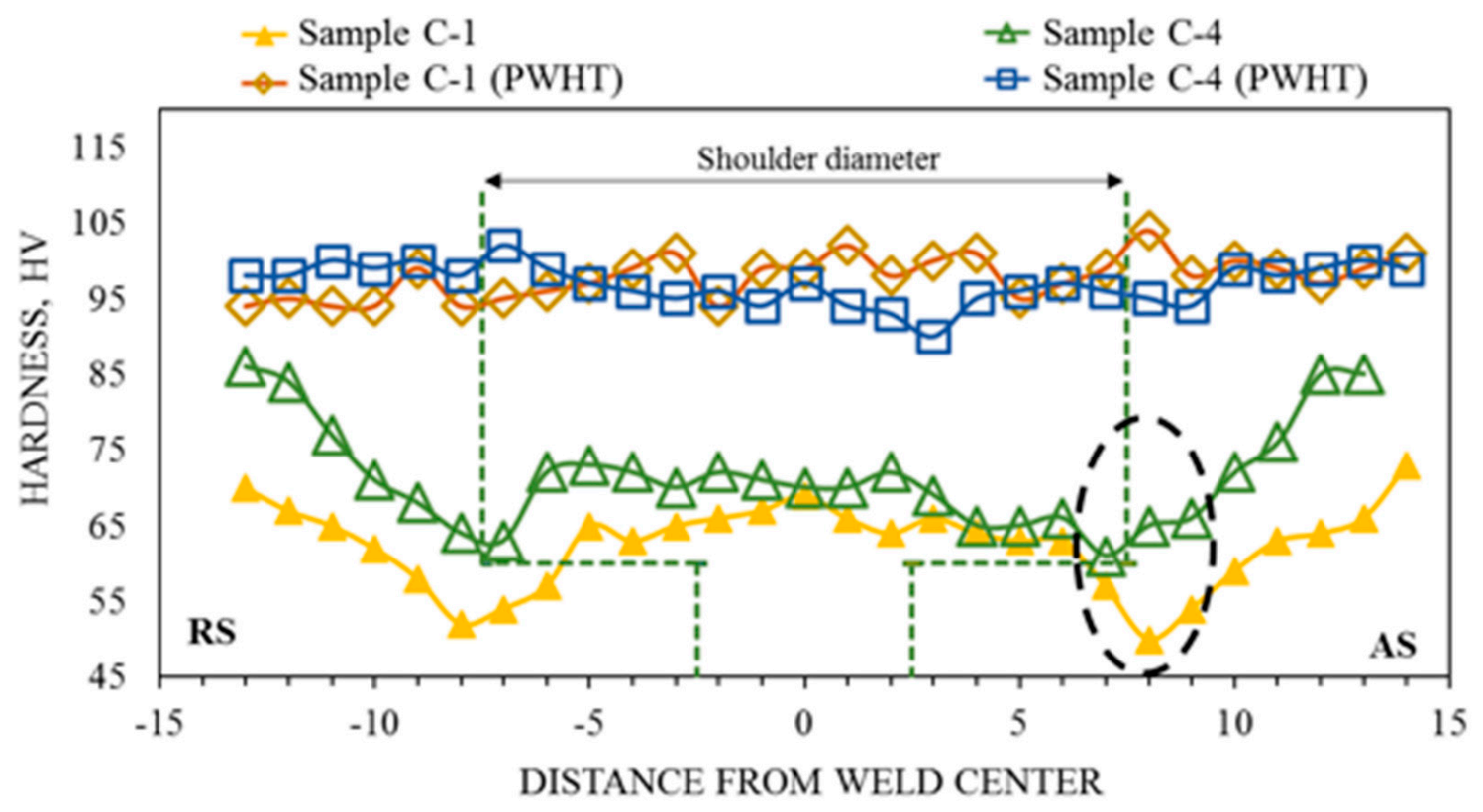

Figure 13. Hardness profile of similar joints of Al6061(T6).

This observation indicated the occurrence of thermal softening. Thus, the coarsening and solutionizing of $\mathrm{Mg}_{2} \mathrm{Si}$, which acted as a strengthening element in the Al matrix, caused a decrease in hardness in the welding zones. The hardness distribution of the HAZ and the TMAZ was improved in the FSW joints by increasing the welding travel speed from 100 to $400 \mathrm{~mm} / \mathrm{min}$, leading to the reduction of the softened zone. This result is attributed to the low precipitation deterioration level in the TMAZ and the HAZ at a high welding travel speed.

The hardness profile of the PWHT samples showed the same hardness profile behavior with low fluctuation on the cross-section of the samples identical to Al6061(T6)-BM and exhibited improved hardness properties by PWHT. The average hardness of $100 \mathrm{HV}$ was obtained after PWHT, and the hardness property of the PWHT samples improved by $54 \%$ compared with that of the FSW samples. In addition, the failure position of similar FSW samples was detected at the HAZ and the TMAZ, but that of the PWHT samples was found in the middle of the samples. These outcomes were consistent with the results obtained from the hardness test. In consideration of the AGG in the welding zone after PWHT, the hardness test of the PWHT samples showed that precipitation hardening particles were the main factors that increased the strength of Al6061(T6) rather than its grain size. Therefore, the variation in hardness is strongly dependent on the precipitates' size, shape, and density rather than their grain structure [50]. 


\section{Conclusions}

This study was conducted to investigate the effect of FSW parameters on AGG during the PWHT in similar joints of Al6061(T6). A T6-heat treatment was performed after the joining process to consider its effect on the microstructure and mechanical properties. The conclusions obtained from the investigation are summarized below.

Sound joints were achieved without any welding defects, such as cracks, porosity, and tunnel, under various rotational and travel speeds. The highest joint efficiency of $71 \%$ was obtained at rotational speed of $1200 \mathrm{rpm}$ and a travel speed of $400 \mathrm{~mm} / \mathrm{min}$. A decrease in the weld strength of the joint was observed after the FSW process due to the dissolution of precipitation hardening particles in the HAZ.

T6-PWHT improved the tensile strength and hardness of similar joints of A16061(T6). However, AGG was observed in the microstructure of PWHT joints because of the heat treatment.

The AGG in the microstructure after the PWHT was governed and may be prevented by adjusting the friction stir welding parameters. In addition, PWHT was able to increase the tensile properties of the joints to values comparable to that of Al6061(T6)-BM. The increased mechanical properties of the joints were attributed to a proper PWHT that resulted in a homogeneous distribution of precipitation hardening phases in the welding zones.

Author Contributions: Conceptualization, A.H.B.; formal analysis, A.H.B. and Z.S.; investigation, A.H.B., Z.S. and A.R.; methodology, A.H.B. and Z.S.; project administration, Z.S. and M.Z.O.; supervision, Z.S. and M.Z.O.; validation, A.H.B.; writing-original draft, A.H.B.; writing-review and editing, Z.S. All authors have read and agreed to the published version of the manuscript.

Funding: This research was funded by Universiti Kebangsaan Malaysia, grant number MI-2019-025.

Conflicts of Interest: The authors declare no conflict of interest.

\section{References}

1. Monajati, H.; Zoghlami, M.; Tongne, A.; Jahazi, M. Assessing Microstructure-Local Mechanical Properties in Friction Stir Welded 6082-T6 Aluminum Alloy. Metals 2020, 10, 1244. [CrossRef]

2. Demir, H.; Gündüz, S. The effects of aging on machinability of 6061 aluminium alloy. Mater. Des. 2009, 30, 1480-1483. [CrossRef]

3. Elangovan, K.; Balasubramanian, V. Influences of post-weld heat treatment on tensile properties of friction stir-welded AA6061 aluminum alloy joints. Mater. Charact. 2008, 59, 1168-1177. [CrossRef]

4. Mrówka-Nowotnik, G.; Sieniawski, J. Influence of heat treatment on the microstructure and mechanical properties of 6005 and 6082 aluminium alloys. J. Mater. Process. Technol. 2005, 162-163, 367-372. [CrossRef]

5. Ozturk, F.; Sisman, A.; Toros, S.; Kilic, S.; Picu, R.C. Influence of aging treatment on mechanical properties of 6061 aluminum alloy. Mater. Des. 2010, 31, 972-975. [CrossRef]

6. Pakdil, M.; Çam, G.; Koçak, M.; Erim, S. Microstructural and mechanical characterization of laser beam welded AA6056 Al-alloy. Mater. Sci. Eng. 2011, 528, 7350-7356. [CrossRef]

7. Çam, G.; Koçak, M. Microstructural and mechanical characterization of electron beam welded Al-alloy 7020 . J. Mater. Sci. 2007, 42, 7154-7161. [CrossRef]

8. Murr, L.E. A review of FSW research on dissimilar metal and alloy systems. J. Mater. Eng. Perform. 2010, 19, 1071-1089. [CrossRef]

9. Mabuwa, S.; Msomi, V. Review on Friction Stir Processed TIG and Friction Stir Welded Dissimilar Alloy Joints. Metals 2020, 10, 142. [CrossRef]

10. Tanaka, T.; Nezu, M.; Uchida, S.; Hirata, T. Mechanism of intermetallic compound formation during the dissimilar friction stir welding of aluminum and steel. J. Mater. Sci. 2020, 55, 3064-3072. [CrossRef]

11. Sajuri, Z.; Selamat, N.F.M.; Baghdadi, A.H.; Rajabi, A.; Omar, M.Z.; Kokabi, A.H.; Syarif, J. Cold-rolling strain hardening effect on the microstructure, serration-flow behaviour and dislocation density of friction stir welded AA5083. Metals 2020, 10, 70. [CrossRef] 
12. Zhang, C.; Huang, G.; Cao, Y.; Li, Q.; Zhu, Y.; Huang, X.; Liu, Q. Investigation on microstructure and localized corrosion behavior in the stir zone of dissimilar friction-stir-welded AA2024/7075 joint. J. Mater. Sci. 2020, 55, 15005-15032. [CrossRef]

13. Hartl, R.; Vieltorf, F.; Zaeh, M.F. Correlations between the Surface Topography and Mechanical Properties of Friction Stir Welds. Metals 2020, 10, 890. [CrossRef]

14. Lu, D.; You, G.; Luo, J.; Ding, Y.; Zeng, S.; Tong, X. Effects of rotational speed on microstructure and mechanical properties of inertia friction-welded 7005-5083 aluminum alloy joints. J. Mater. Sci. 2020, 55, 12338-12352. [CrossRef]

15. Baghdadi, A.H.; Sajuri, Z.; MohamadSelamat, N.F.; Omar, M.Z.; Miyashita, Y.; Kokabi, A.H. Effect of intermetallic compounds on the fracture behavior of dissimilar friction stir welding joints of $\mathrm{Mg}$ and $\mathrm{Al}$ alloys. Int. J. Miner. Metall. Mater. 2019, 26, 1285-1298. [CrossRef]

16. Mishra, R.S.; Ma, Z.Y. Friction stir welding and processing. Mater. Sci. Eng. R Rep. 2005, 50, 1-78. [CrossRef]

17. Baghdadi, A.H.; Selamat, N.F.M.; Sajuri, Z.; Kokabi, A.H. Effect of travel speed on quality and welding efficiency of friction stir welded AZ31B magnesium alloy. Int. J. Eng. Technol. (UAE) 2018, 7, 94-99. [CrossRef]

18. Baragetti, S.; D’Urso, G. Aluminum 6060-T6 friction stir welded butt joints: Fatigue resistance with different tools and feed rates. J. Mech. Sci. Technol. 2014, 28, 867-877. [CrossRef]

19. Huang, Y.; Meng, X.; Lv, Z.; Huang, T.; Zhang, Y.; Cao, J.; Zhou, L.; Feng, J. Microstructures and mechanical properties of micro friction stir welding $(\mu \mathrm{FSW})$ of 6061-T4 aluminum alloy. J. Mater. Res. Technol. 2019, 8, 1084-1091. [CrossRef]

20. Huang, Y.; Meng, X.; Zhang, Y.; Cao, J.; Feng, J. Micro friction stir welding of ultra-thin Al-6061 sheets. J. Mater. Process. Technol. 2017, 250, 313-319. [CrossRef]

21. Osman, N.; Sajuri, Z.; Baghdadi, A.H.; Omar, M.Z. Effect of Process Parameters on Interfacial Bonding Properties of Aluminium-Copper Clad Sheet Processed by Multi-Pass Friction Stir-Welding Technique. Metals 2019, 9, 1159. [CrossRef]

22. Baghdadi, A.H.; Selamat, N.F.M.; Sajuri, Z. Effect of tool offsetting on microstructure and mechanical properties dissimilar friction stir welded $\mathrm{Mg}-\mathrm{Al}$ alloys. In Proceedings of the IOP Conference Series: Materials Science and Engineering, Pahang, Malaysia, 11 July 2017; IOP Publishing: Bristol, UK, 2017; Volume 238, p. 12018.

23. Baghdadi, A.H.; Rajabi, A.; MohamadSelamat, N.F.; Sajuri, Z.; Omar, M.Z. Effect of post-weld heat treatment on the mechanical behavior and dislocation density of friction stir welded Al6061. Mater. Sci. Eng. 2019, 754, 728-734. [CrossRef]

24. Hamed, J.A. Effect of welding heat input and post-weld aging time on microstructure and mechanical properties in dissimilar friction stir welded AA7075-AA5086. Trans. Nonferrous Met. Soc. China 2017, 27, 1707-1715. [CrossRef]

25. Aydin, H.; Bayram, A.; Durgun, I. The effect of post-weld heat treatment on the mechanical properties of 2024-T4 friction stir-welded joints. Mater. Des. 2010, 31, 2568-2577. [CrossRef]

26. Priya, R.; Sarma, V.S.; Rao, K.P. Effect of post weld heat treatment on the microstructure and tensile properties of dissimilar friction stir welded AA 2219 and AA 6061 alloys. Trans. Indian Inst. Met. 2009, 62, 11-19. [CrossRef]

27. İpekoğlu, G.; Erim, S.; Çam, G. Investigation into the influence of post-weld heat treatment on the friction stir welded AA6061 Al-alloy plates with different temper conditions. Metall. Mater. Trans. 2014, 45, 864-877. [CrossRef]

28. İpekoğlu, G.; Çam, G. Effects of initial temper condition and postweld heat treatment on the properties of dissimilar friction-stir-welded joints between AA7075 and AA6061 aluminum alloys. Metall. Mater. Trans. 2014, 45, 3074-3087. [CrossRef]

29. Pabandi, H.K.; Jashnani, H.R.; Paidar, M. Effect of precipitation hardening heat treatment on mechanical and microstructure features of dissimilar friction stir welded AA2024-T6 and AA6061-T6 alloys. J. Manuf. Process. 2018, 31, 214-220. [CrossRef]

30. Khan, N.Z.; Siddiquee, A.N.; Khan, Z.A.; Mukhopadhyay, A.K. Mechanical and microstructural behavior of friction stir welded similar and dissimilar sheets of AA2219 and AA7475 aluminium alloys. J. Alloys Compd. 2017, 695, 2902-2908. [CrossRef]

31. Selamat, N.M.; Baghdadi, A.H.; Sajuri, Z.; Kokabi, A.H.; Junaidi, S. Effect of rolling on strength of friction stir welded joint of aluminium alloys. J. Kejuruter. 2018, 1, 9-15. 
32. Ilangovan, M.; Rajendra Boopathy, S.; Balasubramanian, V. Effect of tool pin profile on microstructure and tensile properties of friction stir welded dissimilar AA 6061-AA 5086 aluminium alloy joints. Def. Technol. 2015, 11, 174-184. [CrossRef]

33. Khan, N.Z.; Siddiquee, A.N.; Khan, Z.A. Friction Stir Welding: Dissimilar Aluminium Alloys; CRC Press: Boca Raton, FL, USA, 2017; ISBN 1351642936.

34. Humphreys, F.J.; Hatherly, M. Recrystallization and Related Annealing Phenomena; Elsevier: Amsterdam, The Netherlands, 2004; ISBN 008098388X.

35. Liu, H.J.; Hou, J.C.; Guo, H. Effect of welding speed on microstructure and mechanical properties of self-reacting friction stir welded 6061-T6 aluminum alloy. Mater. Des. 2013, 50, 872-878. [CrossRef]

36. Malopheyev, S.; Vysotskiy, I.; Kulitskiy, V.; Mironov, S.; Kaibyshev, R. Optimization of processing-microstructure-properties relationship in friction-stir welded 6061-T6 aluminum alloy. Mater. Sci. Eng. 2016, 662, 136-143. [CrossRef]

37. Gungor, B.; Kaluc, E.; Taban, E.; Sik, A. Mechanical, fatigue and microstructural properties of friction stir welded 5083-H111 and 6082-T651 aluminum alloys. Mater. Des. 2014, 56, 84-90. [CrossRef]

38. Gottstein, G. Physical Foundations of Materials Science; Springer Science \& Business Media: Berlin/Heidelberg, Germany, 2013; ISBN 3662092913.

39. Chen, Y.C.; Feng, J.C.; Liu, H.J. Stability of the grain structure in 2219-O aluminum alloy friction stir welds during solution treatment. Mater. Charact. 2007, 58, 174-178. [CrossRef]

40. Charit, I.; Mishra, R.S. Abnormal grain growth in friction stir processed alloys. Scr. Mater. 2008, 58, 367-371. [CrossRef]

41. Ji, S.D.; Meng, X.C.; Liu, J.G.; Zhang, L.G.; Gao, S.S. Formation and mechanical properties of stationary shoulder friction stir welded 6005A-T6 aluminum alloy. Mater. Des. 2014, 62, 113-117. [CrossRef]

42. Ahmed, M.M.Z.; Ataya, S.; Seleman, M.M.E.-S.; Ammar, H.R.; Ahmed, E. Friction stir welding of similar and dissimilar AA7075 and AA5083. J. Mater. Process. Technol. 2017, 242, 77-91. [CrossRef]

43. Selamat, N.F.M.; Baghdadi, A.H.; Sajuri, Z.; Kokabi, A.H. Weldability and mechanical properties of dissimilar al-mgsi to pure aluminium and al-mg using friction stir welding process. J. Teknol. 2019, 81, 143-149. [CrossRef]

44. Abbaschian, R.; Reed-Hill, R.E. Physical Metallurgy Principles; Cengage Learning: Boston, MA, USA, 2008; ISBN 0495082546.

45. Tabatabaei, N.; Taheri, A.K.; Vaseghi, M. Dynamic strain aging of a commercial Al-Mg-Si-Cu alloy during equal channel angular extrusion process. J. Alloys Compd. 2010, 502, 59-62. [CrossRef]

46. Paidar, M.; Sarab, M.L. Friction stir spot welding of 2024-T3 aluminum alloy with SiC nanoparticles. J. Mech. Sci. Technol. 2016, 30, 365-370. [CrossRef]

47. İpekoğlu, G.; Erim, S.; Çam, G. Effects of temper condition and post weld heat treatment on the microstructure and mechanical properties of friction stir butt-welded AA7075 Al alloy plates. Int. J. Adv. Manuf. Technol. 2014, 70, 201-213. [CrossRef]

48. Dong, J.; Zhang, D.; Zhang, W.; Zhang, W.; Qiu, C. Microstructure and properties of underwater friction stir-welded 7003-T4/6060-T4 aluminum alloys. J. Mater. Sci. 2019, 54, 11254-11262. [CrossRef]

49. Singh, R.K.R.; Sharma, C.; Dwivedi, D.K.; Mehta, N.K.; Kumar, P. The microstructure and mechanical properties of friction stir welded Al-Zn-Mg alloy in as welded and heat treated conditions. Mater. Des. 2011, 32, 682-687. [CrossRef]

50. El-Danaf, E.A.; El-Rayes, M.M. Microstructure and mechanical properties of friction stir welded 6082 AA in as welded and post weld heat treated conditions. Mater. Des. 2013, 46, 561-572. [CrossRef]

Publisher's Note: MDPI stays neutral with regard to jurisdictional claims in published maps and institutional affiliations.

(C) 2020 by the authors. Licensee MDPI, Basel, Switzerland. This article is an open access article distributed under the terms and conditions of the Creative Commons Attribution (CC BY) license (http://creativecommons.org/licenses/by/4.0/). 